\title{
Biometric and Bromatological Characteristics of Brachiaria Inoculated With Azospirillum brasilense Associated With Nitrogen Fertilization
}

\author{
Lucas Guilherme Bulegon ${ }^{1}$, Anderson Daniel Suss ${ }^{1}$, Roberto Cecatto Júnior ${ }^{1}$, Vandeir Francisco Guimarães ${ }^{1}$, \\ Deise Dalazen Castagnara ${ }^{2}$, Paulo Sérgio Rabello de Oliveria $^{1} \&$ Leandro Rampim ${ }^{3}$ \\ ${ }^{1}$ Agricultural Sciences Center, Parana Western State University, Marechal Cândido Rondon, PR, Brazil \\ ${ }^{2}$ Department of Veterinary Medicine, Universidade Federal do Pampa, Campus Dom Pedrito, Dom Pedrito, RS, \\ Brazil \\ ${ }^{3}$ Department of Agronomy, State University of Central-West, Campus Cedeteg, Guarapuava, PR, Brazil \\ Correspondence: Vandeir Francisco Guimarães, Agricultural Sciences Center, Parana Western State University, \\ Marechal Cândido Rondon, PR, Brazil. Tel: 55-453-284-7878. E-mail: vandeirfg@yahoo.com.br
}

Received: June 26, 2019

doi:10.5539/jas.v11n16p98
Accepted: July 26, 2019 Online Published: September 30, 2019

URL: https://doi.org/10.5539/jas.v11n16p98

\begin{abstract}
The objective of this study was to evaluate the biometric and bromatological characteristics of Urochloa ruziziensis in due to inoculation times with Azospirillum brasilense in the presence or absence of nitrogen fertilization. To do so it was used a randomized blocks design, with factorial scheme $4 \times 2$, where the first factor consisted the inoculation periods: control; A. brasilense in the seed; A. brasilense at tillering (aerial) and $A$. brasilense seed + foliar. The second factor constituted in the presence or absence of nitrogen $\left(1000 \mathrm{mg} \mathrm{dm}^{3}\right)$. Evaluations were made in the first, second and third cut, being evaluated the plant height, number of tillers per plant, leaves dry mass, culm+sheath dry mass; crude protein content, neutral detergent fiber and acid detergent fiber. The use of nitrogen fertilization increased the productive and bromatological parameters in the crop of $U$. ruziziensis, however, the use of $A$. brasilense increased only the height of plants, not influencing the other productive characteristics and the bromatological parameters. It is concluded that the use of $A$. brasilense, regardless the period it was made, presents inconclusive results for biometric and bromatological characteristics of plants of Urochloa ruziziensis in need of further studies, on the other hand, the nitrogen fertilization brings positive effects over the evaluated parameters on U. ruziziensis.
\end{abstract}

Keywords: nitrogen, crude protein, plant growth promoting bacteria, dry mass

\section{Introduction}

The Brazilian farming and cattle-raising system occupies extensive areas, however, most of them have a low soil natural fertility and/or are cultivated without mineral fertilization (Barcellos et al., 2008), resulting in a low animal support capacity as consequence of the lower biomass production and of forages with low bromatological quality.

The main strategy used to obtain higher productivities and a better pasture quality is in the forage's choice, being preconized those with good adaptability for the cultivation region favoring the plant development even under adverse climatic conditions (Brâncio et al., 2003). In this context, one of the most used species in Brazil is the Urochloa ruziziensis which stands out due to its huge dry mass production besides presenting satisfactory contents of proteins and fibers, with good adaptation to the soil and weather conditions (Mattos, Gomide, \& Huaman, 2005). However, even using local weather adapted forages, animal stocking rates per unit area are reduced, as a consequence of low investment in soil fertility.

To increase pastures quality and productivity, it is necessary the adoption of practices of fertility management, allowing the plants to remove from the soil all the nutrients it needs in adequate and equilibrate amounts (Costa, Oliveira, \& Severino, 2010). Thus, one alternative to reduce the problems with the low-quality pastures in the farming and cattle-raising system is to use mineral fertilizers, such as the nitrogen (Santini, 2014).

Nitrogen is the most demanded nutrient by gramineous forage and directly interferes in the plant's photosynthesis by favoring the photo-assimilates production, influencing the growth rates of leaves and roots (Andrade, 1996). The beneficial effects of nitrogen fertilization over gramineous forage are mentioned by 
Fagundes et al. (2005) where the supply of nitrogen doses increased the dry mass production of Brachiaria decumbens. Similar results are reported by Rodrigues et al. (2008), where it was also evidenced increases in the total dry mass production of Brachiaria brizantha, with linear increases as a function of nitrogen doses.

One alternative to help the gramineous forage production system in association with the sustainability of the agricultural system, is by using the inoculation with Azospirillum brasilense. The inoculation with A. brasilense represents a direct effect over pastures, because it provides plant hormones such as auxin, gibberellin and cytokinin which improve the root development, stimulating the absorption of water and nutrients, leading to increases in the productivity and in the pasture quality (Neto et al., 2013). Besides the already mentioned effects, the inoculation with $A$. brasilense favors increases in photosynthesis, increasing the chlorophyll foliar contents (Barassi, Coli, \& Elliott, 2008).

Another advantage of the pasture inoculation with $A$. brasilense is due to the possibility of this technique to partially dispense the mineral nitrogen fertilizer due to a better use of the soil nutrients as the inoculated plants present greater development of the root system allowing greater soil exploration and consequently greater absorption of nutrients, reducing production costs (Magalhães et al., 2011).

Therefore, the objective of this study was to evaluate the biometric and bromatological characteristics of Urochloa ruziziensis in due to inoculation times with Azospirillum brasilense in the presence or absence of nitrogen fertilization.

\section{Material and Methods}

The experiment was conducted into a protected environment with roofs in arc, covered with low density polyethylene film with $150 \mu$ thickness and anti-UV protection, with sides protected with white screen with $40 \%$ shading, at the experimental station Professor Dr. Mario César Lopes, located at the coordinates-2 $24^{\circ} 558^{\prime} \mathrm{S}$ and $54^{\circ} 045^{\prime}$ W, located at the State University of Western Paraná (UNIOESTE), Marechal Cândido Rondon, Paraná. For the experiment conduction a substrate made by sand and dirt from the horizon A of an Oxisoil was used, in the proportion of three parts of soil to one part of sand, which was homogenized and placed in plastic pots with capacity to $6 \mathrm{dm}^{3}$ of substrate, being that at the moment when the experiment was installed the substrate presented the chemical characteristics shown at (Table 1).

Table 1. Chemical and physical characteristics of a substrate proveniente from the mixture of an Oxisol (horizon A) with sand compound in the proportion 3:1, respectively, 2015/2016

\begin{tabular}{lllllllllll}
\hline $\mathrm{P}$ & $\mathrm{OM}$ & $\mathrm{pH}$ & $\mathrm{H}+\mathrm{Al}$ & $\mathrm{Al}^{3+}$ & $\mathrm{K}^{+}$ & $\mathrm{Ca}^{2+}$ & $\mathrm{Mg}^{2+}$ & $\mathrm{B}$ & $\mathrm{CEC}$ & $\mathrm{V}$ \\
\hline $\mathrm{mg} \mathrm{dm}^{-3}$ & $\mathrm{~g} \mathrm{dm}^{-3}$ & $\mathrm{CaCl}_{2}$ & $-2 .--1.0$ & -0.00 & 0.09 & 3.10 & 1.05 & 4.24 & 7.04 & 60.28 \\
10.15 & 1.10 & 5.55 & 2.80 & 0.00 & 0.04 &
\end{tabular}

Note. $\overline{\mathrm{OM}}=$ Organic matter; $\mathrm{CEC}=$ Cation exchange capacity; $\mathrm{V}=$ Percent Saturation of Bases; $\mathrm{P}$ and $\mathrm{K}$ $\left(\right.$ Mehlich $\left.^{-1}\right) ; \mathrm{Ca}, \mathrm{Mg}$ and $\mathrm{Al}^{3+}(\mathrm{KCl} 1 \mathrm{~mol}) ; \mathrm{Al}+\mathrm{H}\left(\right.$ calcium acetate $\left.0.5 \mathrm{~mol} \mathrm{~L}^{-1}\right)$.

For the fertilization with phosphorus and potassium it was used $300 \mathrm{mg} \mathrm{dm}^{-3}$ of $\mathrm{P}_{2} \mathrm{O}_{5}$ as singles superphosphate and $150 \mathrm{mg} \mathrm{dm}^{-3}$ of $\mathrm{K}_{2} \mathrm{O}$ as potassium chloride (Novais, Neves, \& Barros, 1991), before the crop was sowed, with no nitrogen fertilization being made at this moment.

For the experiment conduction it was adopted a randomized block design, in factorial scheme $4 \times 2$ with five replicates, where the first factor was represented by the inoculation periods with $A$. brasilense (4 treatments) being: control; $A$. brasilense in the seed; $A$. brasilense in tillering (aerial) (15 days after emergence of plants) and A. brasilense in the seed+tiller. The second factor represented the presence or absence of nitrogen fertilization. Plants were evaluated for three cutting periods, which were called first cut, second cut and third cut.

For the crop sowing were used seeds from the specie Urochloa ruziziensis with cultural value of $60 \%$, being conducted two plants per pot. For the treatments which received inoculation with $A$. brasilense via seed, the inoculation was made in a flux chamber, ensuring the asepsis and the non-contamination by other microorganisms, using $1 \mathrm{~mL}$ of commercial inoculant with A. brasilense strains AbV5 and AbV6 in the concentration of $2 \times 10^{8} \mathrm{CFU} \mathrm{mL}^{-1}$ for each 1000 seeds, being the sowing made around $30 \mathrm{~min}$ after the inoculation.

For the treatments in which the inoculation was made at the crop tillering, it was made with a backpack sprayer pressurized with $\mathrm{CO}_{2}$, with a 3-meter-wide wand and 6 flat spray nozzles (Magno 11002 ADGA), work pressure of $2.2 \mathrm{bar}$, flow rate of $250 \mathrm{~L} \mathrm{ha}^{-1}$ and application height $0.5 \mathrm{~m}$ above the apex of the plants. For the $A$. brasilense 
it was used the commercial liquid inoculant strains AbV5 and AbV6, concentration of $2 \times 10^{8} \mathrm{CFU} \mathrm{mL}^{-1}$ and dose of $0.3 \mathrm{~L} \mathrm{ha}^{-1}$ of inoculant, being this application made at nighttime which favors the bacterial survival.

For the plants that received the nitrogen fertilization a dose of $100 \mathrm{mg} \mathrm{dm}^{-3}$ was used, being this application held in installments, providing $500 \mathrm{mg} \mathrm{dm}^{-3}$ at the crop tillering and $250 \mathrm{mg} \mathrm{dm}^{-3}$, three days after the cut, using urea as nitrogen source ( $45 \%$ nitrogen).

Pots were kept irrigated, with daily reposition of water and the plants were constantly monitored to ensure an adequate development, not being necessary the realization of cultural managements on the U. ruziziensis at 35 days after emergence of plants the first cut was evaluated, the second cut was evaluated 65 days after emergence of plants and the third cut was evaluated 95 days after emergence of plants, being the cuts realized to a height of $15 \mathrm{~cm}$ of the substrate surface, for grazing simulation.

For the evaluation of biometric characteristics, first it was determined the plant height $(\mathrm{cm})$, being it considered from the substrate surface up to the tip of the tallest leave. The number of tillers was manually counted, after the forage was cut at $15 \mathrm{~cm}$ height. Next plants were separated in leaves and culm+sheat and stored in paper bags which were taken to an air forced circulation oven at $65^{\circ} \mathrm{C}$ for 72 hours, and posteriorly weighed in an analytical scale, for the obtention of leaves dry mass and culm+sheath dry mass, being these values expressed in $\mathrm{g} \mathrm{plant}^{-1}$.

For the determination of the bromatological composition, after plants were dried and determined the dry mass contents, the dry samples of leaves and culm+sheath were homogenized and mowed in a Willey type mower, with a 30-mesh sieve and stored in previously identified plastic bags. In the sequence the crude protein (CP) content was determined according to Aoac (1990), for the neutral detergent fiber (NDF) and acid detergent fiber (ADF) it was used the methodology proposed by Silva and Queiroz (2006).

All data was tabulated and submitted to variance analysis for each cut and, when pertinent, means were compared by the Tukey test at $5 \%$ of probability.

\section{Results and Discussion}

For the biometric variables evaluated during the development of the braquiaria crop, meaningful results were observed for the isolated factors or for its interaction in at least one of the cuts for all the varieties $(p \leq 0.05)$.

In the first cut the plant height parameter was not significantly influenced by the studied factors $(p>0.05)$. In the second cut it was observed it was observed effect of the interaction of the factors, where on the treatments without nitrogen fertilization, the smallest average was provided by the control, being $25 \%, 19 \%$ and $21 \%$ inferior to the seed inoculation, foliar application and the combination, respectively. The highest average for the treatments with nitrogen fertilization occurred in the control, however, only differing from the inoculation seed + foliar, which presented a reduction of $23 \%$ (Table 2 ).

Table 2. Plant height and number of tillers of Urochloa ruziziensis submitted to different periods of inoculation with Azospirillum brasilense, in the presence or absence of nitrogen fertilization

\begin{tabular}{|c|c|c|c|c|c|c|}
\hline \multirow{2}{*}{ Treatments } & \multicolumn{2}{|c|}{$1^{\text {st }}$ cut } & \multicolumn{2}{|c|}{$2^{\text {nd }}$ cut } & \multicolumn{2}{|c|}{$3^{\text {rd }}$ cut } \\
\hline & Without N & With N & Without N & With N & Without N & With N \\
\hline \multicolumn{7}{|c|}{ Plant height $(\mathrm{cm})$} \\
\hline Control & $48.33^{\mathrm{ns}}$ & $48.33^{\mathrm{ns}}$ & $59.00 \mathrm{bB}$ & $88.33 \mathrm{aA}$ & $37.00^{\mathrm{ns}}$ & $40.83^{\mathrm{ns}}$ \\
\hline Seed $(S)$ & $37.66^{\mathrm{ns}}$ & $44.00^{\mathrm{ns}}$ & $79.00 \mathrm{aA}$ & $80.66 \mathrm{abA}$ & $47.50^{\mathrm{ns}}$ & $45.33^{\mathrm{ns}}$ \\
\hline Foliar $(\mathrm{F})$ & $54.33^{\mathrm{ns}}$ & $43.50^{\mathrm{ns}}$ & $73.62 \mathrm{aA}$ & $75.16 \mathrm{abA}$ & $44.66^{\mathrm{ns}}$ & $43.50^{\mathrm{ns}}$ \\
\hline $\mathrm{S}+\mathrm{F}$ & $50.33^{\mathrm{ns}}$ & $48.00^{\mathrm{ns}}$ & $75.00 \mathrm{aA}$ & $68.00 \mathrm{bA}$ & $49.33^{\mathrm{ns}}$ & $50.33^{\mathrm{ns}}$ \\
\hline Average & 47.66 & 45.95 & $72.04 \mathrm{~B}$ & $77.65 \mathrm{~A}$ & 44.62 & 45.00 \\
\hline $\mathrm{CV}(\%)$ & 22.66 & & 8.46 & & 18.56 & \\
\hline \multicolumn{7}{|c|}{ Number of tillers } \\
\hline Control & $9.55^{\mathrm{ns}}$ & $10.50^{\mathrm{ns}}$ & $9.88 \mathrm{aA}$ & $12.55 \mathrm{aA}$ & $7.27 \mathrm{aB}$ & $13.77 \mathrm{aA}$ \\
\hline Seed (S) & $8.22^{\text {ns }}$ & $10.94^{\mathrm{ns}}$ & $7.66 \mathrm{aB}$ & $12.33 \mathrm{aA}$ & $5.66 \mathrm{aB}$ & $9.55 \mathrm{aA}$ \\
\hline Foliar $(\mathrm{F})$ & $9.72^{\mathrm{ns}}$ & $8.16^{\mathrm{ns}}$ & $7.94 \mathrm{aA}$ & $10.33 \mathrm{aA}$ & $5.66 \mathrm{aB}$ & $9.66 \mathrm{aA}$ \\
\hline $\mathrm{S}+\mathrm{F}$ & $8.66^{\mathrm{ns}}$ & $8.88^{\mathrm{ns}}$ & $7.44 \mathrm{aB}$ & $10.77 \mathrm{aA}$ & $5.44 \mathrm{aB}$ & $7.66 \mathrm{aA}$ \\
\hline Average & 9.04 & 9.62 & $8.23 \mathrm{~B}$ & $11.50 \mathrm{~A}$ & $6.01 \mathrm{~B}$ & $10.16 \mathrm{~A}$ \\
\hline $\mathrm{CV}(\%)$ & 16.51 & & 19.22 & & 34.99 & \\
\hline
\end{tabular}

Note. ${ }^{\text {ns }}$ not significant by the $\mathrm{F}$ test at $5 \%$ probability; Means followed by the same lowercase letter in the column and upper case in the row do not differ from each other by the Tukey test at $5 \%$ probability. 
Evaluating the number of tillers per plant, no significant effect of inoculation of $A$. brasilense and nitrogen fertilization was observed $(p>0.05)$. In the second cut it is observed effect of the factors interaction, being that in the treatments without nitrogen fertilization the different inoculation forms did not differ among each other, in the same way occurring for the factor with $\mathrm{N}$, between the treatments smallest averages occurred for the seed inoculation and seed+foliar inoculation which had a decrease of $38 \%$ and $31 \%$ in relation to its respective treatment with $\mathrm{N}$. In the third cut an interaction of the factors was observed, being that independent of inoculation, plants that did not receive mineral $\mathrm{N}$ had lower averages, with an average increase of $60 \%$ in the number of tillers for the plants with nitrogen fertilization $(\mathrm{p}>0.05)$ (Table 2).

Inoculation with $A$. brasilense favors physiological parameters in plants, increasing the leaves chlorophyll content, stomatal conductance, hydric potential, water content, elasticity, increasing production and height of inoculated plants (Barassi et al., 2008). Thus, the increases in plant height with inoculation in the absence of N, are due to the benefits provided by the $A$. brasilense that favors the plant development (Pedraza, 2008) due to the higher absorption of water and nutrients from the soil (Neto et al., 2013).

The increase in the number of tillers of plants fertilized with nitrogen is associated to the fundamental role that this nutrient has on plants, as the main constituent of proteins that act in the synthesis of organic compounds which constitute the plant structure, such as the tillers (Costa, Paulino, \& Magalhães, 2006). Therefore, it is shown that the deficit of $\mathrm{N}$ on $B$. decumbens is associated to the drastic reduction in the number of tillers (Silva et al., 2009).

Similar results to the present study are highlighted by Alexandrino et al. (2005), that, after evaluating the development of $B$. brizantha cv. Marandu submitted to cuts and nitrogen fertilization, report a difference in the crop tillering, being the smallest tillering observed in the third cut, as in the present study.

Considering the positive results of the nitrogen fertilization in relation to the plant's height and number of tillers in the second cut (Table 2), these are linked to nitrogen development functions on plants, as component of the structure of molecules and enzymes responsible for the plant vegetative development (Marchner, 1995). Besides, the nitrogen exercises a direct influence in the photosynthesis, consequently in the photoassimilates production, influencing the growth rates of roots and leaves, being the plant growth the most evident effect of the addition of this nutrient (Andrade, 1996).

When the culm+sheath dry mass and leaves dry mass are analyzed, it is observed that there was no significant effect of the interaction between the factors studied in the first and third cuts $(p>0.05)$, still in these cuts it was observed an isolated effect for the nitrogen fertilization where in the first cut the fertilized plants promoted averages that were $27.65 \%$ and $12 \%$ higher for the leaves dry mass and culm+sheath dry mass, respectively. In the third cut it was observed that plants fertilized with $\mathrm{N}$ promoted averages that were $14.25 \%$ and $46.18 \%$ higher for the leaves dry mass and culm+sheath dry mass, respectively (Table 3 ).

Table 3. Leaves dry mass and culm + sheath dry mass $\left(\mathrm{g} \mathrm{plant}^{-1}\right)$ of Urochloa ruziziensis submitted to different periods of inoculation with Azospirillum brasilense, in the presence or absence of nitrogen fertilization

\begin{tabular}{|c|c|c|c|c|c|c|}
\hline \multirow{2}{*}{ Treatments } & \multicolumn{2}{|c|}{$1^{\text {st }}$ cut } & \multicolumn{2}{|c|}{$2^{\text {nd }}$ cut } & \multicolumn{2}{|c|}{$3^{\text {rd }}$ cut } \\
\hline & Without N & With N & Without N & With N & Without N & With N \\
\hline \multicolumn{7}{|c|}{ Leaves dry mass $\left(g\right.$ plant $\left.^{-1}\right)$} \\
\hline Control & $5.20^{\mathrm{ns}}$ & $7.82^{\mathrm{ns}}$ & $4.33 \mathrm{aB}$ & $7.58 \mathrm{aA}$ & $3.47^{\mathrm{ns}}$ & $4.24^{\mathrm{ns}}$ \\
\hline Seed (S) & $4.27^{\mathrm{ns}}$ & $5.36^{\mathrm{ns}}$ & $3.85 \mathrm{aB}$ & $7.42 \mathrm{aA}$ & $2.99^{\mathrm{ns}}$ & $3.99^{\mathrm{ns}}$ \\
\hline Foliar $(\mathrm{F})$ & $4.78^{\mathrm{ns}}$ & $4.82^{\mathrm{ns}}$ & $4.36 \mathrm{aB}$ & $6.59 \mathrm{aA}$ & $4.31^{\mathrm{ns}}$ & $4.70^{\mathrm{ns}}$ \\
\hline $\mathrm{S}+\mathrm{F}$ & $4.26^{\mathrm{ns}}$ & $5.65^{\mathrm{ns}}$ & $3.84 \mathrm{aB}$ & $6.61 \mathrm{aA}$ & $3.58^{\mathrm{ns}}$ & $3.12^{\mathrm{ns}}$ \\
\hline Average & $4.63 \mathrm{~B}$ & $5.91 \mathrm{~A}$ & $4.09 \mathrm{~B}$ & $7.05 \mathrm{~A}$ & $3.51 \mathrm{~B}$ & $4.01 \mathrm{~A}$ \\
\hline $\mathrm{CV}(\%)$ & 28.76 & & 22.48 & & 16.08 & \\
\hline \multicolumn{7}{|c|}{ Culm + sheath dry mass (g plant $\left.{ }^{-1}\right)$} \\
\hline Control & $3.61^{\mathrm{ns}}$ & $3.71^{\mathrm{ns}}$ & $2.39 \mathrm{aB}$ & $7.09 \mathrm{aA}$ & $3.73^{\mathrm{ns}}$ & $5.57^{\mathrm{ns}}$ \\
\hline Seed (S) & $3.16^{\mathrm{ns}}$ & $3.67^{\mathrm{ns}}$ & $3.69 \mathrm{aB}$ & $6.56 \mathrm{aA}$ & $2.94^{\mathrm{ns}}$ & $4.41^{\mathrm{ns}}$ \\
\hline Foliar $(\mathrm{F})$ & $3.18^{\mathrm{ns}}$ & $3.20^{\mathrm{ns}}$ & $2.99 \mathrm{aA}$ & $5.37 \mathrm{aA}$ & $3.16^{\mathrm{ns}}$ & $4.27^{\mathrm{ns}}$ \\
\hline $\mathrm{S}+\mathrm{F}$ & $3.00^{\mathrm{ns}}$ & $3.96^{\mathrm{ns}}$ & $3.48 \mathrm{aA}$ & $5.47 \mathrm{aA}$ & $2.75^{\mathrm{ns}}$ & $4.12^{\mathrm{ns}}$ \\
\hline Average & $3.24 \mathrm{~B}$ & $3.63 \mathrm{~A}$ & $3.14 \mathrm{~B}$ & $6.13 \mathrm{~A}$ & $3.14 \mathrm{~B}$ & $4.59 \mathrm{~A}$ \\
\hline $\mathrm{CV}(\%)$ & 11.69 & & 34.21 & & 32.46 & \\
\hline
\end{tabular}

Note. ${ }^{\text {ns }}$ not significant by the $\mathrm{F}$ test at $5 \%$ probability; Means followed by the same lowercase letter in the column and upper case in the row do not differ from each other by the Tukey test at $5 \%$ probability. 
In the second cut, for both parameters leaves dry mass and culm+sheath dry mass, no differences were observed in the treatments with or without N. In the leaves dry mass, for the factor's interaction, it was evidenced that plants fertilized with nitrogen promoted higher averages, independent the treatment applied, with average increase of $42 \%$ in the leaves dry mass of Urochloa ruziziensis. For the culm+sheath dry mass in the factors interaction it was observed that the supply of $\mathrm{N}$ increased the control average and the seed inoculation with $A$. brasilense average (Table 3 ).

The increases in dry mass, due to the supply of nitrogen fertilization, occurred because of the functions performed by the element in plants, where it acts in the foliar expansion, favoring the interception of the photosynthetically active radiation, acting directly on the photosynthesis of the plants culminating with an increase in the dry leaf biomass production (Andrade, 1996). Thos way the nitrogen fertilization influences the plant growth, accelerating the formation of new leaves and improving the vigor of regrowth after the cuts (Cecato et al., 1996).

In this sense is demonstrated that the nitrogen fertilization increased the leaves dry mass of "marandu" grass (Silva et al., 2013). In plants of "braquiaria", Alcantara (2018), showed that the supply of nitrogen right after the cuts promotes increases in the leaves dry mass. Lastly, Benett et al. (2008), in study with doses of nitrogen in $B$. brizantha cv Marandu, verified that increasing doses of up to $200 \mathrm{~kg} \mathrm{ha}^{-1}$ resulted in increases in the dry mass production.

When considering the supply caused by the plant growth promotion bacteria $A$. brasilense, it is observed that the results of the present study are inconclusive in relation to the capacity to raise the dry mass of plants. These results may have occurred by the cultivation condition, which was in pots, where the increases in the root system are limited by its exploration area, as that no hydric limitation occurred, condition where the use of $A$. brasilense brings increases to tropical pastures (Bulegon, Inagaki, Moratelli, Costa, \& Guimarães, 2017). It is worth mentioning that the absence of conclusive results in the present study, provided by the inoculation with $A$. brasilense, may be associated with the genetic characteristics of the used material, where the study was conducted beyond the intervals between inoculation and evaluation (Alcântara, 2018).

Thus, results that corroborate with the present study with A. brasilense are reported by Mumbach (2017), who verified that on grasses inoculated with $A$. brasilense without $\mathrm{N}$ supply, no changes on the leaves dry mass were observed. However, when there was an association of $50 \%$ of the $\mathrm{N}$ dose with inoculation with A. brasilense, increases in the dry mass are observed when compared to the fertilization with $100 \%$ of the dose.

Even though in the present study no positive results were evidenced by the use of inoculation with A. brasilense in grass forages, according to the literature positive results can be found. Thus, Oliveira, Oliveira, \& Baroni (2007), studying B. brizantha cv. Marandu, observed that plants inoculated with A. brasilense and without $\mathrm{N}$ supply, produced higher leaves dry mass in relation to the control. Magalhães et al. (2011), found that the inoculation of forage plants from the genus Panicum with $A$. brasilense promoted increases in the pasture total dry mass, with similar averages to the treatments which received nitrogen fertilization, concluding that this technique can be used as a tool do dismiss, partially, the use of a chemical nitrogen source.

For the crude protein content in the first cut there was no significant variation between treatments in the absence of nitrogen fertilization (Table 4). When observing the treatments with nitrogen fertilization the seed inoculation with $A$. brasilense promoted higher average, surpassing in $7.73 \%$ the control. When the factors with and without $\mathrm{N}$ are evaluated, the presence of $\mathrm{N}$ promoted a superior average for all treatments, being obtained an increase of $23.6 \%$ in average values.

In the second cut, in the absence of nitrogen, the highest average was obtained in the control and in the seed + foliar inoculation. The treatments that received nitrogen, the smallest average was obtained in the control, with reduction of $16.8 \%$ in relation to the seed inoculation. In the third cut, in the absence of $\mathrm{N}$, the highest average was obtained in the treatment with seed+foliar inoculation, surpassing in $11.46 \%$ the control, in the presence of $\mathrm{N}$, the smallest average was obtained in the control. When it is observed the treatments with and without $\mathrm{N}$, except for the ones with foliar application of $A$. brasilense, the highest averages were obtained in the presence of nitrogen (Table 4).

Thus, the use of nitrogen fertilization helps in the increase on the crude protein content. The present results corroborate with the ones obtained in B. brizantha cv. "Marandu" submitted to nitrogen fertilization where the crude protein content increased (Martins, 2015). Benett et al. (2008), also observed that the supply of nitrogen increased the crude protein in the first and third cut, where the control presented an average of $10.65 \%$ and the treatments with nitrogen presented $17.67 \%$ of crude protein, corroborating with the results of this study. 
For high quality pastures, high crude protein contents are required, so the animal's protein demand is fulfilled, once that contents inferior to $7 \%$ limit the dry mass digestibility, compromising the animal's nutrition (Van Soest, 1994). In this sense, the nitrogen fertilization helps to increase the protein content in "braquiaria" (Epstein \& Bloom, 2005). However, in the present study, only for the first cut the required parameters for proteins were reached, being that in the second and third cut these values were next to the required.

Table 4. Crude protein (\%) of Urochloa ruziziensis submitted to different periods of inoculation with Azospirillum brasilense, in the presence or absence of nitrogen fertilization

\begin{tabular}{|c|c|c|c|c|c|c|}
\hline \multirow{2}{*}{ Treatments } & \multicolumn{2}{|c|}{$1^{\text {st }}$ cut } & \multicolumn{2}{|c|}{$2^{\text {nd }}$ cut } & \multicolumn{2}{|c|}{$3^{\text {rd }}$ cut } \\
\hline & Without N & With N & Without N & With N & Without N & With N \\
\hline Control & $12.47 \mathrm{aB}$ & $16.23 \mathrm{bA}$ & $7.32 \mathrm{aA}$ & $5.63 \mathrm{bB}$ & $5.41 \mathrm{bB}$ & $6.13 \mathrm{bA}$ \\
\hline Seed (S) & $13.10 \mathrm{aB}$ & $17.49 \mathrm{aA}$ & $6.60 \mathrm{bA}$ & $6.58 \mathrm{aA}$ & $4.34 \mathrm{cB}$ & $6.67 \mathrm{aA}$ \\
\hline Foliar (F) & $13.61 \mathrm{aB}$ & $15.42 \mathrm{bA}$ & $5.69 \mathrm{cB}$ & $6.93 \mathrm{aA}$ & $5.65 \mathrm{bA}$ & $6.50 \mathrm{aB}$ \\
\hline $\mathrm{S}+\mathrm{F}$ & $12.87 \mathrm{aB}$ & $15.17 \mathrm{bA}$ & $6.34 \mathrm{abA}$ & $6.58 \mathrm{aA}$ & $6.03 \mathrm{aB}$ & $6.62 \mathrm{aA}$ \\
\hline Average & $13.01 \mathrm{~B}$ & $16.08 \mathrm{~A}$ & 6.49 & 6.43 & $5.36 \mathrm{~B}$ & $6.48 \mathrm{~A}$ \\
\hline $\mathrm{CV}(\%)$ & 3.98 & & 5.58 & & 3.12 & \\
\hline
\end{tabular}

Note. ${ }^{\text {ns }}$ not significant by the $\mathrm{F}$ test at $5 \%$ probability; Means followed by the same lowercase letter in the column and upper case in the row do not differ from each other by the Tukey test at $5 \%$ probability.

The absence of responses to A. brasilense is due to a current condition, the fact that it is a plant growth promoting bacterium and not a nitrogen fixing bacterium as the first studies. It is emphasized that it fixes nitrogen, but it does not have the capacity to supply significant amounts of plants to the point of increasing the leaf nitrogen concentration and consequently the crude protein content. Thus, Kappes et al. (2013), mention that, there is a concordance in the literature that the advantages of the association of plants with Azospirillum spp. are more related to the plant growth promotion, mainly the root system, than to the nitrogen biological fixation.

For the neutral detergent fiber (Table 5), in the first cut, the treatments in the absence of $\mathrm{N}$ presented distinct behaviors with the smallest average obtained in the seed inoculation with $A$. brasilense but without differing from the foliar application of $A$. brasilense. In the factor's interaction, the control and the foliar application of $A$. brasilense exhibited smallest averages in the presence of $\mathrm{N}$. In the second cut, when treatments were kept without nitrogen, higher averages were observed in the control and in the seed + foliar application of $A$. brasilense. In the factor's interaction, the treatments seed inoculation and foliar application of $A$. brasilense showed variations, with higher averages being observed when they received nitrogen (Table 5).

In the third cut without nitrogen the highest average occurred in the seed inoculation with $A$. brasilense, however, without differing from the seed + foliar inoculation. In the factor's interaction, it is observed that only the seed inoculation with $A$. brasilense showed variations, being the highest average obtained in the absence of nitrogen. When treatments received nitrogen, they did not differ among themselves in none of the evaluated cuts.

For the parameter acid detergent fiber in the first cut no differences were observed for the treatments without nitrogen fertilization, when they were fertilized with $\mathrm{N}$ the highest average was obtained with the application of A. brasilense via seed + foliar, which did not differ from the foliar application with $A$. brasilense. Considering the treatments, except for the seed + foliar application of $A$. brasilense, the other treatments provided superior averages in the presence of nitrogen fertilization. In the second cut no differences were observed for the studied factors (Table 5).

In the third cut, in the treatments without $\mathrm{N}$, the smallest average was obtained in the control, however, differing only from the seed inoculation with $A$. brasilense, with a reduction of $14.88 \%$. In the treatments with nitrogen fertilization the smallest average was obtained with the seed inoculation with $A$. brasilense, however, differing only from the control, being that only for this treatment it was observed differences between plants with or without nitrogen, with highest average for plants without nitrogen fertilization.

The fiber content evaluation in forages is fundamental for the evaluation of the forage's nutritional quality. According to Aguiar (1999), contents above $65 \%$ of NDF in the regrowth are considered as a critical level, where plants with NDF contents on these standards present a low nutritive value. In the present study, the seed inoculation or foliar inoculation with $A$. brasilense reduced the NDF below the critical levels in the second and third cut, considered the ones with the lowest bromatological quality of the forage. Costa, Oliveira, and Faquin 
(2009), mention that plants with low percentage of acid detergent fiber (ADF) have better digestibility of the dry mass, once the ADF is correlated to the food digestibility, because the indigestible fiber is in it.

Table 5. Neutral detergent fiber (NDF) and acid detergent fiber (ADF) of Urochloa ruziziensis submitted to different periods of inoculation with Azospirillum brasilense, in the presence or absence of nitrogen fertilization

\begin{tabular}{|c|c|c|c|c|c|c|}
\hline \multirow{2}{*}{ Treatments } & \multicolumn{2}{|c|}{$1^{\text {st }}$ cut } & \multicolumn{2}{|c|}{$2^{\text {nd }}$ cut } & \multicolumn{2}{|c|}{$3^{\text {rd }}$ cut } \\
\hline & Without N & With N & Without N & With N & Without N & With N \\
\hline \multicolumn{7}{|c|}{ Neutral detergent fiber (\%) } \\
\hline Control & $62.62 \mathrm{aA}$ & $55.54 \mathrm{aB}$ & $65.61 \mathrm{aA}$ & $65.11 \mathrm{aA}$ & $62.05 \mathrm{abA}$ & $61.41 \mathrm{aA}$ \\
\hline Seed $(S)$ & $57.77 \mathrm{bA}$ & $54.96 \mathrm{aA}$ & $60.98 \mathrm{bB}$ & $63.99 \mathrm{aA}$ & $69.77 \mathrm{aA}$ & $61.42 \mathrm{aB}$ \\
\hline Foliar (F) & $60.30 \mathrm{abA}$ & $54.38 \mathrm{aB}$ & $58.80 \mathrm{bB}$ & $66.49 \mathrm{aA}$ & $58.71 \mathrm{bA}$ & $63.45 \mathrm{aA}$ \\
\hline $\mathrm{S}+\mathrm{F}$ & $61.22 \mathrm{aA}$ & $59.00 \mathrm{aA}$ & $65.40 \mathrm{aA}$ & $66.35 \mathrm{aA}$ & $66.68 \mathrm{abA}$ & $64.20 \mathrm{aA}$ \\
\hline Average & $60.48 \mathrm{~A}$ & $55.97 \mathrm{~B}$ & $62.93 \mathrm{~B}$ & $65.25 \mathrm{~A}$ & 64.30 & 62.62 \\
\hline $\mathrm{CV}(\%)$ & 4.17 & & 2.85 & & 8.01 & \\
\hline \multicolumn{7}{|c|}{ Acid detergent fiber (\%) } \\
\hline Control & $36.04 \mathrm{aA}$ & $29.04 \mathrm{bB}$ & $34.26^{\mathrm{ns}}$ & $29.60^{\mathrm{ns}}$ & $32.04 \mathrm{bA}$ & $33.13 \mathrm{aA}$ \\
\hline Seed $(S)$ & $34.12 \mathrm{aA}$ & $30.24 \mathrm{bB}$ & $29.58^{\mathrm{ns}}$ & $32.96^{\mathrm{ns}}$ & $36.81 \mathrm{aA}$ & $28.91 \mathrm{bB}$ \\
\hline Foliar $(\mathrm{F})$ & $34.54 \mathrm{aA}$ & $30.87 \mathrm{abB}$ & $38.17^{\mathrm{ns}}$ & $35.37^{\mathrm{ns}}$ & $35.10 \mathrm{abA}$ & $31.61 \mathrm{abA}$ \\
\hline $\mathrm{S}+\mathrm{F}$ & $34.48 \mathrm{aA}$ & $34.18 \mathrm{aA}$ & $28.65^{\mathrm{ns}}$ & $34.04^{\mathrm{ns}}$ & $33.71 \mathrm{abA}$ & $33.00 \mathrm{abA}$ \\
\hline Average & $34.79 \mathrm{~A}$ & $31.09 \mathrm{~B}$ & $32.67^{\mathrm{ns}}$ & $33.08^{\mathrm{ns}}$ & $34.42 \mathrm{~A}$ & $31.66 \mathrm{~B}$ \\
\hline $\mathrm{CV}(\%)$ & 5.94 & & 19.61 & & 6.34 & \\
\hline
\end{tabular}

Note. ${ }^{\text {ns }}$ not significant by the F test at 5\% probability; Means followed by the same lowercase letter in the column and upper case in the row do not differ from each other by the Tukey test at 5\% probability.

It is worth mentioning that raises in NDF and ADF is associated to the drops in the protein content which were found, thus, plants with lower protein content have higher fiber contents, culminating in a low nutritive value (Patês et al., 2008). The nitrogen fertilization also raises the crude protein content in the dry mass, being the proteins synthetized from the carbohydrates, this way, the increases in the nitrogen compounds and proteins end up diluting the cell wall fraction, reducing the NDF and ADF (Van Soest, 1994). Thus, in study evaluating nitrogen sources in the crop of B. brizantha cv. "Xaraés", Santini (2014), verified that the supply of nitrogen reduced the ADF.

Considering the above, the use of nitrogen fertilization in $U$. ruziziensis crop raises the biometric and bromatological parameters, however, the use of the plant growth promoting bacterium A. brasilense does not interfere in the productive characteristics except for the height of plants. When considering cultivated plants without nitrogen fertilization the seed inoculation with $A$. brasilense raises the bromatological characteristics of the plants, in relation to the other treatments studied, however, it does not replace the use of nitrogen fertilization in the totality, because when inoculated the seeds and provided mineral nitrogen, the plants had better bromatological characteristics, thus allowing new studies when considering this technique of supply of $A$. brasilense under forage grass conditions.

\section{Conclusion}

The use of inoculation with Azospirillum brasilense regardless of the period, whether via seed, foliar or foliar + seed, presents inconclusive results for biometric and bromatological characteristics of plants of Urochloa ruziziensis in need of further studies.

The use of nitrogen fertilization increases the biometric and bromatological characteristics of plants of Urochloa ruziziensis.

\section{Acknowledgements}

This study was financed in part by the Coordenação de Aperfeiçoamento de Pessoal de Nível Superior - Brasil (CAPES).

\section{References}

Alcântara, G. B. (2018). Response of cultivars of Brachiaria spp. Azospirillum brasilense and nitrogen fertilization (22 f., Graduation in Agronomy, Evangelical Faculty of Goianésia, Goianésia, Brazil). 
Alexandrino, E., Nascimento Junior, D., Regazzi, A. J., Mosquim, P. R., Rocha, F. C., \& Souza, D. P. (2005). Morphogenic and structural characteristics of Brachiaria brizantha cv. Marandu submitted to different doses of nitrogen and frequencies of cuts. Acta Scientiarum, 27(1), 7-14. https://doi.org/10.4025/ actasciagron.v27i1.1902

Aguiar, A. P. A. (1999). Possibilities of intensification of the use of the pasture through rotation without or with minimum use of fertilizers. Symposium on pasture management: Fundamentals of rotational grazing, Piracicaba, Anais.

Andrade, J. B. (1996). Effects of nitrogen fertilization on the production and composition of Brachiaria ruziziensis forage. Pesquisa Agropecuária Brasileira, 31(9), 617-620.

AOAC (Association of Official Analytical Chemists). (1990). Official methods of analytical of the Association of Official Analytical Chemists (15th ed., p. 656). Washington: AOAC.

Barassi, M. R., Cole, M. A., \& Elliott, R. J. R. (2008). Stochastic Divergence or Convergence of Per Capita Carbon Dioxide Emissions: Re-examining the Evidence. Environ Resource Econ, 40(1), 121-137. https://doi.org/10.1007/s10640-007-9144-1

Barcellos, A. O. (2008). Sustainability of animal production based on intercropping pastures and use of exclusive legumes, in the form of a protein bank, in the Brazilian tropics. Revista Brasileira de Zootecnia, 37(1) 51-67.

Benett, C. G. S., Buzetti, S., Silva, K. S., Bergamaschine, A. F., \& Fabricio, J. A. (2008). Productivity and bromatological composition of marandu grass at nitrogen sources and rates. Science and agro-technology, 32(5), 1629-1636. https://doi.org/10.1590/S1413-70542008000500041

Brâncio, P. A., Euclides, V. P. B., Nascimento Jr., D., Fonseca, D. M., Almeida, R. G., Macedo, M. C. M., \& Barbosa, R. A. (2003). Evaluation of three Cultivars of Panicum maximum Jacq. under Grazing: Forage Availability, Post-Grazing Residue Height and Leaf, Harvest, and Dead Material Participation. Brazilian Journal of Zootecnia, 32(1), 55-63. https://doi.org/10.1590/S1516-35982003000500003

Bulegon, L. G., Inagaki, A. M., Moratelli, G., Costa, N. V., \& Guimarães, V. F. (2017). Phytotoxicity of mesotrione in maize inoculated with Azospirillum brasilense associated with nitrogen fertilization. Brazilian Journal of Agricultural Sciences, 12(3), 325-331. https://doi.org/10.5039/agraria.v12i3a5459

Cecato, U., Santos, G. T., Machado, M. A., Gomes, L. H., Damaceno, J. C., Jobim, C. C... Cano, C. C. P. (1996). Evaluation of cultivars of the genus Cynodon. Annual Meeting of the Brazilian Zootechnical Society, 33, Fortaleza. Anais... Fortaleza, SBZ.

Costa, K. A. P., Faquin, V., \& Oliveira, I. P. (2009). Nitrogen doses and sources in the mineral nutrition of Marandu grass. Cienc. Animal Bras, 10(1), 115-123.

Costa, K. A. P., Oliveira, I. P., \& Faquin, V. (2010). Nitrogen doses and sources in the pasture recovery of Marandu grass. Brazilian Archives of Veterinary Medicine and Animal Science, 62(1), 192-199. https://doi.org/10.1590/S0102-09352010000100026

Costa, K. A. P., Oliveira, I. P., Severiano, E. C., Sampaio, F. M. T., Carrijo, M. S., \& Rodrigues, C. R. (2010). Extraction of nutrients by biomass of Brachiaria brizantha cultivars under nitrogen doses. Brazilian Animal Science, 11(2), 307-31.

Costa, N. L., Paulino, V. T., \& Magalhães, J.A. (2006). Forage production, chemical composition and morphogenesis of Panicum maximum cv. Winner under different levels of nitrogen fertilization. Rev Sci Prod Anim, 8(1), 66-72.

Epstein, E., \& Bloom, A. J. (2005). Mineral nutrition of plants: Principles and perspective (2nd ed., p. 400). Sunderland: Sinauer Associates.

Fagundes, J. L., Fonseca, D. M., Gomide, J. A., Junior, D. N., Vitor, C. M. T., Morais, R. V., ... Martuscello, J. A. (2005). Fodder accumulation in Brachiaria decumbens pastures fertilized with nitrogen. Brazilian Agricultural Research, 40(4), 397-403. https://doi.org/10.1590/S0100-204X2005000400012

Kappes, C., Orivaldo, A. R. F., Ferreira, J. P., Dal Bem, E.A., Portugal, J. R., \& Vilela, R. G. (2013). Inoculation of seeds with diazotrophic bacteria and application of nitrogen in cover and leaf in corn. Semina Agrarian Sciences, 34(2), 527-538. https://doi.org/10.5433/1679-0359.2013v34n2p527 
Magalhães, A.F., Pires, A. J. V., Carvalho, G. G. P., Sousa, R. S., Silva, F. F., Bonomo, P., ... Perreira, M. (2011). Bromatological composition and nutrient concentrations of Brachiaria grass fertilized with nitrogen and phosphorus. Brazilian Journal of Animal Health and Production, 12(4), 893-907.

Marchner, H. (1995) Mineral nutrition of higher plants (2nd ed., p. 889). London: Academic Press.

Martins, F. A. D., Andrade, A. T., Condé, A. B. T., Godinho, D. B., Caixeta, C. G., Costa, R. L., ... Soares, C. M. S. (2015). Evaluation of corn hybrids inoculated with Azospirilum brasilense. Pesquisa Agropecuária Gaúcha, 18(2), 103-110.

Mattos, J. L. S., Gomide, J. A., \& Huaman, C. A. M. (2005). Growth of species of the genus Brachiaria, under water deficit, under greenhouse conditions. Brazilian Journal of Zootecnia, 34(3), 746-754. https://doi.org/ $10.1590 / \mathrm{S} 1516-35982005000300006$

Mumbach, M. R., \& Satpathy, A. T. (2017). Enhancer connectome in primary human cells identifies target genes of disease-associated DNA elements. Nature Genetics, 49(1), 1602-1612. https://doi.org/10.1038/ng.3963

Neto, F. J. D., Yoshimi, F. K., Garcia, R. D., Miyamoto, Y. R., \& Domingues, M. C. S. (2013). Development and yield of green maize in response to leaf application with Azospirillum brasilense. Encyclopedia Biosfera, 9(17), 1030.

Novaes, R. F. De, Neves, J. C. L., \& Barros, N. F. DE (1991). Controlled environment test. In A. J. Oliveira, W. E. Garrido, J. D. Araujo, \& S. Lourenço (Eds.), Methods of research in soil fertility (pp. 189-253). Brasília DF: Embrapa-SE.

Oliveira, A. P. P., Oliveira S. W., \& Baroni, W. (2007). Forage production and quality of Brachiaria brizantha cv. Marandu with Azospirillum brasilense and fertilized with nitrogen (Technical Circular 54, p. 6). São Carlos: EMBRAPA.

Patês, N. M. S., Pires, A. J. V., Carvalho, G. P., Oliveira, A. C., Foncêca, M. P., \& Veloso, C. M. (2008). Production and nutritive value of Tanzania grass fertilized with nitrogen and phosphorus. Revista Brasileira de Zootecnia, 37(11), 1934-1939. https://doi.org/10.1590/S1516-35982008001100005

Pedraza, R. O. (2008). Recent advances in nitrogen-fixing acetic acid bacteria. International Journal of Food Microbiology, 125(1), 25-35. https://doi.org/10.1016/j.ijfoodmicro.2007.11.079

Rodrigues, R. C., Mourão, G. B., Brennecke, K., Luz, P. H. C., \& Herling, V. R. (2008). Production of dry mass, leaf/stem ratio and some growth indices of Brachiaria brizantha cv. Xaraés cultivated with the combination of doses of nitrogen and potassium. Revista Brasileira de Zootecnia, 37(3), 394-400. https://doi.org/ $10.1590 / \mathrm{S} 1516-35982008000300003$

Santini, J. M. K. (2014). Sources and doses of nitrogen in the culture of Brachiaria brizantha cv. Xaraés under cerrado soil and climatic conditions (Dissertation 70 f., Masters in Agronomy, Universidade Estadual Paulista, Ilha Solteira, Brazil).

Silva, C. C. F., Bonomo, P., Pires, A. J. V., Maranhão, C. M. A., Patês, N. M. S., \& Santos, L. C. (2009). Morphogenic and structural characteristics of two Brachiaria species fertilized with different nitrogen doses. Rev Bras Zootecn, 38(4), 657-661. https://doi.org/10.1590/S1516-35982009000400010

Silva, D. R. G., Costa, K. A. P., Faquin, V., Oliveira, I. P., \& Bernardes, T. F. (2013). Nitrogen doses and sources in the recovery of the structural and productive characteristics of the marandu grass. Science and Agro-Technology, 44(1), 1806-6690. https://doi.org/10.1590/S1806-66902013000100023

Van Soest, P. J. (1994). Nutritional ecology of the ruminant (2nd ed.). New York: Cornell University.

\section{Copyrights}

Copyright for this article is retained by the author(s), with first publication rights granted to the journal.

This is an open-access article distributed under the terms and conditions of the Creative Commons Attribution license (http://creativecommons.org/licenses/by/4.0/). 